\title{
Influence of nematode Anguillicoloides crassus infestation on the cellular and humoral innate immunity in European eel (Anguilla anguilla L.)
}

\author{
ELŻBIETA TERECH-MAJEWSKA', PATRYCJA SCHULZ², ANDRZEJ K. SIWICKI \\ ${ }^{1}$ Department of Epizootiology, University of Warmia and Mazury in Olsztyn, Poland \\ ${ }^{2}$ Department of Microbiology and Clinical Immunology, University of Warmia and Mazury in Olsztyn, Poland \\ ${ }^{3}$ Department of Fish Pathology and Immunology, The Stanislaw Sakowicz IFI in Olsztyn, Poland
}

\begin{abstract}
Parasitic invasions are recognized as one of the primary factors responsible for decreasing populations of European eel. The aim of the present study was to determine the influence of infestation with the nematode Anguillicoloides crassus on the innate immunity in European eel (Anguilla anguilla). Anguillicoloides crassus parasitizes the swim bladder of this fish. Levels of the following immunological parameters were measured: spleen phagocyte respiratory burst activity, spleen phagocyte potential killing activity, pronephros lymphocyte proliferation stimulated by concanavaline A or lipopolisaccharide, plasma lysozyme and ceruloplasmin activity, total protein and immunoglobulin (Ig) serum levels. The analyses of the results of humoral and cellular immunity indicate that all studied parameters were statistically significant higher $(p<0.05)$ in non-infested fish compared to the ones with anguillicolosis except for ceruloplasmin level. These data suggest that the A. crassus infestation in European eel is responsible for a decreased immune response what could result in higher susceptibility to other pathogenic conditions.
\end{abstract}

Key words: fish, parasite, helminthes, immunological system.

(Centr Eur J Immunol 2015; 40 (2): 127-131)

\section{Introduction}

The European eel (Anguilla anguilla) is a catadromous fish with a complicated life cycle. The species migrates over $5000 \mathrm{~km}$ to spawning grounds in the Sargasso Sea $[1,2]$. The intensive rearing of European eels is systematically developing in many countries. It is one of the most important warm water fish cultures in European and Asian countries. Long-term economic increasing importance, the impact of anthropopressure on the environment, environmental pollution, and diseases have led to a risk of extinction. The increasing economic importance of fish parasitosis for aquaculture and fisheries has enhanced the interest in the defence mechanisms against these infestations. Both innate and adaptive immune responses are mounted by fish to control parasite infestations [3].

Parasitic invasions are recognised as one of the primary factors responsible for decreasing populations of European eel [4]. One of the major diseases of the European eel in open waters is anguillicolosis, which is a parasitosis of many species of eels (Anguilla sp.) caused by nematodes of the family Anguillicolidae. In the European eel it is caused by Anguillicoloides crassus (Kuwahara, Niimi, and
Itagaki, 1974) [5]. This parasite was introduced to Europe in the early 1980s, probably with infected Japanese eel imported from Taiwan [6]. A wide range of paratenic and intermediate hosts in the aquatic environment has allowed A. crassus to spread very rapidly throughout Europe [7]. It spread across the continent very quickly and today almost completely corresponds to the reach of the geographical incidence of European eel, from North Africa to Scandinavia, with the exception of Iceland [8]. The success of these parasites depends on small fish, snails, tadpoles of frogs, aquatic insects, and newts, acting as paratenic hosts and transmitting the nematode to eels $[9,10]$.

Anguillicoloides crassus parasitises the swim bladder of eel. Infestations in European eel can lead to deteriorated condition and poor health, and in extreme cases, death [1113]. Pathological studies of the impact of A. crassus on the European eel in the wild and on farms indicate that these fish experience acute inflammation, fibrosis, and severe thickening of the swim bladder wall causing its lumen and size to decrease [12].

Similar to other fish species, the innate immune system in eels comprises a large number of physical, cellular, and

Correspondence: Patrycja Schulz, Department of Microbiology and Clinical Immunology, University of Warmia and Mazury in Olsztyn, Poland, e-mail: patrycja.schulz@uwm.edu.pl 
humoral factors that act as the first line of defence against invading organisms such as viruses, bacteria, and parasites $[14,15]$. Few experimental studies have been carried out in fish, and it well established in vivo that macrophages, neutrophils, eosinophils, and lymphocytes can be involved in the host response to nematodes. Many parasites invade and establish in body tissues and fluids where they are able to survive by virtue of a range of adaptations that reduce the efficacy of the immune system. Invasion of, and establishment in, the swim bladder may confer on the parasite freedom from aggressive immunological responses [16].

The aim of the present study was to determine the influence of infestation with the nematode Anguillicoloides crassus on the innate immunity in the European eel ( $A n$ guilla anguilla).

\section{Material and methods}

The study involved fish used to restock Szczecin Lagoon in 2011. Fish came from a fish farm involved in rearing eel fry. The average length of the fish was $162 \mathrm{~mm}$ with a mean body weight of $5.32 \mathrm{~g}$. The fish were anaesthetised with Propiscin (IFI, Poland) and peripheral blood was drawn from the caudal vein by Vacutainer system into two tubes: heparinised and non-heparinised (Vacutainer set - Vacuette Greiner Labortechnik; $50 \mathrm{IU} / \mathrm{ml}$ of heparin), and the fish were then euthanised. The spleen and pronephros of each fish were removed aseptically. After the autopsy and examination of the swim bladder the samples were assigned to the appropriate group. In order to determine the cellular and humoral defence mechanism parameters 20 samples from each group were examined.

The spleen and pronephros of each fish were removed aseptically and single cell suspensions were obtained for isolating individual cells using either Gradisol (Polfa) or Histopaque-1077 (Sigma) gradients, as described by Siwicki and Dunier [17]. To determine the number of viable cells from the pronephros or spleen, the cells were stained with trypan blue (Sigma) and then counted after three washings with culture medium RPMI-1640 containing L-glutamine (Sigma).

The metabolic activity of spleen phagocytes was determined based on the measurement of intracellular respiratory burst (RBA) after stimulation by PMA (phormol myristate acetate, Sigma), as described by Siwicki et al. [18]. The isolated cells were resuspended in RPMI-1640 medium (Sigma) at $1 \times 10^{6}$ cells $/ \mathrm{ml}$. On 96-well U-shaped microplates $100 \mu \mathrm{l}$ of isolated spleen leukocytes were mixed with of $100 \mu \mathrm{l}$ of $0.2 \%$ nitro blue tetrazolium (NBT) solution at $\mathrm{pH} 7.2$, and $1 \mu \mathrm{l}$ of PMA was added. After 30 minutes of incubation at $22^{\circ} \mathrm{C}$ the supernatant was removed from each well. The cell pellets were washed with absolute ethanol and then three times in $70 \%$ ethanol and dried at room temperature. The amount of extracted reduced NBT after incubation with $2 \mathrm{M} \mathrm{KOH}$ and DMSO (dimethyl sulfox- ide, Sigma) was measured colourimetrically at $620 \mathrm{~nm}$ in a plate microreader (MRX 3 Dynatech). All samples were tested in triplicate and the mean value served as the result.

The potential killing activity (PKA) of spleen phagocytic cells was determined according to the method presented by Siwicki et al. [18]. On 96-well U-shaped microplates $100 \mu \mathrm{l}$ of leucocytes from spleen were mixed with $100 \mu \mathrm{l}$ of $0.2 \%$ NBT and $10 \mu \mathrm{l}$ of live Aeromonas hydrophila was added (containing $1 \times 10^{6}$ bacteria/ml). The mixture was incubated for 30 minutes at $22^{\circ} \mathrm{C}$ and the supernatant was removed. The cell pellet was washed with absolute ethanol and three times with $70 \%$ ethanol and dried at room temperature. This was followed by the addition of $2 \mathrm{M} \mathrm{KOH}$ and DMSO to each well. The amount of extracted reduced NBT was measured at $620 \mathrm{~nm}$ in a plate microreader (MRX 3 Dynatech). All samples were tested in triplicate and the mean value served as the result.

The proliferative response of pronephros lymphocytes (LP) stimulated by mitogen concanavaline A (ConA, Sigma) or lipopolysaccharide (LPS, Sigma) was determined by MTT assay, previously described by Wagner et al. [19] and adapted for fish species by Siwicki et al. [20]. On 96-well culture plates (Costar, USA) $100 \mu$ of pronephros lymphocytes in RPMI 1640 containing 10\% FCS, 2 mM L-glutamine, $0.02 \mathrm{~m} \mathrm{M}$ 2-mercaptoethanol, 1\% HEPES buffer, and penicillin/streptomycin $(100 \mathrm{U} / 100 \mu \mathrm{g} / \mathrm{ml})$ were mixed with $100 \mu$ of RPMI 1640 containing mitogens ConA $(5 \mu \mathrm{g} / \mathrm{ml})$ or LPS $(20 \mu \mathrm{g} / \mathrm{ml})$. After 72 hours of incubation at $22^{\circ} \mathrm{C}$ without carbon dioxide atmosphere, $50 \mu \mathrm{l}$ of MTT solution were added into each well and the plates were incubated at $22^{\circ} \mathrm{C}$ for 4 hours. After incubation the plates were centrifuged (1400 g, 5 minutes). Supernatants were removed and $100 \mu \mathrm{l}$ of DMSO (Sigma) were added into each well and incubated for 15 minutes at room temperature. After incubation the solubilised reduced MTT was measured colourimetrically at $620 \mathrm{~nm}$ in a plate microreader (MRX 3 Dynatech). All samples were tested in triplicate and the mean value served as the result.

The lysozyme activity in plasma was measured by turbidimetric assay [21]. The assay is based upon the lysis of the lysozyme-sensitive Gram positive bacterium Micrococcus lysodeikticus (Sigma), which is obtained freeze-dried from major chemical suppliers. A solution of Micrococcus lysodeikticus in sodium phosphate buffer was mixed with plasma and incubated at $25^{\circ} \mathrm{C}$. The absorbance $(450 \mathrm{~nm})$ was measured before and after 15 minutes of incubation in sterile plastic tubes. The standard was hen egg white lysozyme (Sigma).

The ceruloplasmin activity in the plasma was determined spectrophotometrically [22] modified for micro-methods in fish [23]. The plasma was incubated in microplates for 15 minutes in acetate buffer containing $0.2 \%$ p-phenylenediamine (PPD, Sigma). Sodium azide $(0.02 \%)$ was used to stop the reaction. The ceruloplasmin 
activity was measured at $540 \mathrm{~nm}$ on a microreader (MRX 3 Dynatech).

Analysis of total protein and immunoglobulin (Ig) levels in serum was based on the Lowry micro method (Sigma, Diagnostic Kits). The total Ig level was measured using the Lowry micro method adapted for fish species by Siwicki \& Anderson [21]. This method requires first precipitating the immunoglobulin out of the serum with polyethylene glycol $(10,000 \mathrm{kDa})$.

The results from three sets of experiments were pooled. The mean values and standard deviations from pooled experiments were used for comparison between the groups. Statistical significance was evaluated with the use of Statgraphics 2.1 Win and Statistica 5.77 software (analysis of variance, comparison of regression lines, Wilcoxon's twin pair analysis). For all calculations $p<0.05$ was assumed as significant.

\section{Results}

Comparison of the innate cellular and humoral defence mechanisms in healthy fish and European eel with anguillicolosis are presented in Table 1. The analyses of the results showed that phagocytic ability (RBA) and PKA of spleen phagocytes were statistically significant higher $(p<0.05)$ in European eel free of nematode compared to the fish with the identified parasites. The similar pattern was observed in proliferative response of blood lymphocytes stimulated by mitogens ConA or LPS. The analyses of the results of humoral immunity indicate that almost all studied parameters were statistically significant higher $(p<0.05)$ in non-infested fish compared to the ones with anguillicolosis. Only statistically significant $(p<0.05)$ lower levels of ceruloplasmin in healthy fish were observed.

\section{Discussion}

Fish are the first animal phyla to possess both an innate and an adaptive immune system making them very interesting as regards developmental studies of the immune system. The massive extension in aquaculture in recent decades has also put greater emphasis on studies of fish immune system and defence mechanisms against diseases commonly associated with intensive fish rearing. The objective of the present study was to determine the influence of infestation with the nematode $A$. crassus on the innate immunity in the European eel (Anguilla anguilla). This basic examination provides very important information about physiological levels of nonspecific humoral and cellular protection against pathogens in different health conditions: with and without parasitic infestation.

Nematode infestation exhibits stressors in infected fish and increases susceptibility to stress. Young fish are especially sensitive to stress due to infestation by the L3 stage [24]. The spread of parasite A. crassus infestation is very diverse. The extent and intensity of infestation is dependent on water salinity and the age and size of the fish. The nematode was noticed in brackish water and freshwater breeding farms [25-27]. The infestation prevalence in the European eel may be as high as $90-100 \%$ with a very high intensity of 30 nematodes in a single fish [28-30]. Such a high infestation level cannot remain harmless to the condition of the fish. A study by Knopf and Lucius (2008) [31] suggests that $A$. japonica as the original host of $A$. crassus is able to mount efficient protective immune responses against its parasite, whereas the newly acquired host seems to lack this ability.

Phagocytosis is one of the main mechanisms involved in the host's protective responses leading to the clearance of pathogens. The analyses of the results showed that the phagocytic ability (RBA) and PKA of spleen phagocytes were statistically significant higher $(p<0.05)$ in fish free of infestation, compared to fish with parasitosis. These results agree with observations by Muńoz et al. [32]. Macrophages seem to play an important role in the immune response to helminth parasites in fish. Macrophages and granulocytes around $A$. crassus larvae in the swim bladder wall do not seem to attack the L3 and L4 [33], but it is believed that this cellular response plays an essential role

Table 1. Innate cellular and humoral immune defence in healthy eels and in eels with nematode Anguillicoloides crassus infestation (infection) in natural conditions (mean $\pm \mathrm{SD}, n=20 ; *$ statistically significant $p<0.05$ )

\begin{tabular}{ccc}
\hline $\begin{array}{c}\text { Immunological } \\
\text { parameters: }\end{array}$ & $\begin{array}{c}\text { Group of fish free } \\
\text { of nematode }\end{array}$ & $\begin{array}{c}\text { Group of fish } \\
\text { with identified } \\
\text { nematode }\end{array}$ \\
\hline $\begin{array}{c}\text { Metabolic activity of } \\
\text { spleen phagocytes RBA } \\
\text { (OD 620 nm) }\end{array}$ & $0.45 \pm 0.05^{*}$ & $0.32 \pm 0.03$ \\
\hline $\begin{array}{c}\text { Potential killing activity } \\
\text { of spleen phagocytes } \\
\text { (OD 620 nm) }\end{array}$ & $0.40 \pm 0.04^{*}$ & $0.29 \pm 0.04$ \\
\hline $\begin{array}{c}\text { Pronephros lymphocyte } \\
\text { proliferation stimulated } \\
\text { by ConA (OD 620 nm) }\end{array}$ & $0.47 \pm 0.04^{*}$ & $0.34 \pm 0.04$ \\
\hline $\begin{array}{c}\text { Pronephros lymphocyte } \\
\text { proliferation stimulated } \\
\text { by LPS (OD 620 nm) }\end{array}$ & $0.40 \pm 0.05^{*}$ & $0.27 \pm 0.03$ \\
\hline $\begin{array}{c}\text { Lysozyme activity } \\
\text { in plasma (mg/l) }\end{array}$ & $12.4 \pm 1.6^{*}$ & $7.6 \pm 1.2$ \\
\hline $\begin{array}{c}\text { Ceruloplasmin activity } \\
\text { in plasma (IU) }\end{array}$ & $62.5 \pm 5.0^{*}$ & $93.5 \pm 3.5$ \\
\hline $\begin{array}{c}\text { Total protein level } \\
\text { in serum (g/l) }\end{array}$ & $54.5 \pm 3.0^{*}$ & \\
\hline $\begin{array}{c}\text { Total Ig level in serum } \\
\text { (g) }\end{array}$ & $12.6 \pm 1.4^{*}$ & \\
\hline & & \\
\hline & & \\
\hline & & \\
\hline
\end{tabular}


in the development of immunity against $A$. crassus because it results in fibrosis that is thought to inhibit invasion of further juveniles [34]. The macrophage malfunction could be the result of an increase in the stress level, and a direct effect of the parasite itself.

The similar pattern was observed in the proliferative response of pronephros lymphocytes stimulated by mitogens ConA or LPS. The results showed that the proliferative response of lymphocytes was statistically significantly $(p<0.05)$ higher in European eel without nematode (Table 1). The results showed that infected eels do not have higher cell mediated immunity, which suggests that the presence of the parasite in the swim bladder inhibits the innate cellular immune response, an important line of defence mechanisms and protection against diseases.

The humoral factors of innate defence mechanisms presented by lysozyme and ceruloplasmin activity in plasma, total protein, and Ig levels in serum are shown in Table 1 . The results indicate that the lysozyme and total protein and Ig levels in serum were statistically significantly higher $(p<0.05)$ in non-infested eel. This enzyme activity could be dependent on the degree of stress, as well as its intensity and its duration and the type of stressors [35], and the presence of parasites in the swim bladder induces chronic stress in eels. Lysozyme has antiviral, antibacterial, and anti-inflammatory properties, but high lysozyme can result in a significantly higher mortality in fish challenged with pathogens [36, 37].

Only statistically significantly $(p<0.05)$ lower levels of ceruloplasmin (Cp) in healthy fish were observed. Ceruloplasmin is an acute phase protein. Its function is to modulate the immune response. It inhibits bacterial development by depriving it of essential nutrients, i.e. copper ions [38]. Ceruloplasmin is found to be activated by the host immune system during stress conditions. Although high levels of this protein seem to prevent secondary bacterial or viral infections, in this case it is more certainly associated with stress caused by infestation with A. crassus.

Serum proteins play an important role in the transport of different substances, defence of the organism against pathological agents, and some other functions. Fish physiological status, age, season, and habitats play a role in serum protein properties. Total protein level and total Ig levels in serum were significantly declined in A. crassus infected eels compared with non-infected.

Knowledge of the eel immune system is of importance to maintain good health throughout the grow-out period in eel farms. In summary, our results suggest that $A$. crassus infestation in European eels could be responsible for a decreased immune response, which would result in higher susceptibility to other pathogenic conditions.

\section{The authors declare no conflict of interest.}

\section{References}

1. Tesch FW (1982): The Sargasso Sea eel expedition 1979. Helgol Mar Res 35: 63-77.

2. van den Thillart G, Dufour S (2009): How to estimate reproductive success of European eels. In: Spawning Migration of the European Eel. van den Thillart G, Dufour S, Rankin JC (eds.). Springer; 3-9.

3. Alvarez-Pellitero P (2008): Fish immunity and parasite infections: from innate immunity to immunoprophylactic prospects. Vet Immunol Immunopathol 126: 171-198.

4. Székely C, Palstra A, Molnar K, van den Thillart G (2009): Impact of the swimbladder parasite on the health and performance of European Eel. Spawning Migration of the Eel. Fish and Fisheries Series 30: 201-226.

5. Rolbiecki L (2011): New distribution data for the invasive nematode Anguillicoloides crassus (Kuwahara, Niimi et Itagaki, 1974) in the eel, Anguilla anguilla, in Polish waters. Kom Ryb 4: 9-13.

6. Křie M (1991): Swimbladder nematodes (Anguillicola spp.) and gill monogeneans (Pseudodactylogyrus spp.) parasitic on the European eel (Anguilla anguilla). J Cons Int Explor Mer 47: 391-398.

7. Sures B, Knopf K, Würtz J, Hirt J (1999): Richness and diversity of parasite communities in European eels Anguilla anguilla of the River Rhine, Germany, with special reference to helminth parasites. Parasitology 119: 323-330.

8. ICES (2011): Report of the 2011 session of the Joint EIFAAC/ ICES Working Group on Eels. EIFAAC Occasional Paper, No. 48, ICES CM 2011/ACOM: 18, Rome, FAO/Copenhagen, Lisbon, Portugal, September 5-9, 2011, 246.

9. Rolbiecki L (2002): On the role of paratenic hosts in the life cycle of the nematode Anguillicola crassus in the Vistula Lagoon, Poland. Acta Ichthyol Piscat 32: 109-116.

10. Moravec F, Skoríková B (1998): Amphibians and larvae of aquatic insects as new paratenic hosts of Anguillicola crassus (Nematoda: Dracunculoidea), a swimbladder parasite of eels. Dis Aquat Organ 34: 217-222.

11.Egusa S (1979): Notes on the culture of the European eel (Anguilla anguilla) in Japanese eel farming ponds. Rapp. P.-v. Réun. Cons Int Explor Mer 174: 51-58.

12. Molnar K, Baska F, Csaba G, et al. (1993): Pathological and histopathological studies of the swimbladder of eels Anguilla anguilla infected by Anguillicola crassus (Nematoda: Dracunculoidea). Dis Aquat Organ 15: 41-50.

13. Molnar K, Székely C, Baska F (1991): Mass mortality of eel Lake Balaton due to Anguillicola crassus infection. Bull Eur Ass Fish Pathol 11: 211-212.

14. Nielsen ME, Esteve-Gassent MD (2006): The eel immune system: present knowledge and the need for research. J Fish Dis 29: 65-78.

15. Uribe C, Folch H, Enriquez R, Moran V (2011): Innate and adaptive immunity in teleost fish: a review. Vet Med-Czech 56: 486-503.

16. Secombes CJ, Chappell LH (1996): Fish immune responses to experimental and natural infection with helminth parasites. Ann Rev Fish Dis 6: 167-177.

17. Siwicki AK, Cossarini-Dunier M (1990): Effect of levamisole on the lymphocyte and macrophage activity in carp (Cyprinus carpio). Ann Rech Vet 21: 95-100.

18. Siwicki AK, Klein P, Morand M, et al. (1998): Immunostimulatory effects of dimerized lysozyme (KLP-602) on the nonspecific defence mechanisms and protection against furunculosis in salmonids. Vet Immunol Immunopathol 61: 369-378. 
19. Wagner U, Burkhardt E, Failing K (1999): Evaluation of canine lymphocyte proliferation: comparison of three different colorimetric methods with the $\mathrm{H}$-thymidine incorporation assay. Vet Immunol Immunopathol 70: 151-159.

20. Siwicki AK, Morand M, Kazuń B, et al. (2003): In vitro immunomodulating influence of methisoprinol on the head kidney phagocyte and lymphocyte activity after suppression induced by VHSV in rainbow trout (Oncorhynchus mykiss). Pol J Vet Sci 3: 51-53.

21. Siwicki AK, Anderson DP (1993): Nonspecific defence mechanisms assay in fish. Fish Disease Diagnosis and Prevention's Methods. FAO-Project GCP/INT/526/JPN, IFI Olsztyn; 105112.

22. Rice EW, Wagman E, Takenaka Y (1986): Ceruloplasmin assay in serum: standarization of ceruloplasmin activity in terms of international enzyme units. Diagn Lab 12: 39-53.

23. Siwicki AK, Studnicka M (1986): Ceruloplasmin activity in carp (Cyprinus carpio). Bamidgeh 38: 126-129.

24. Sures B, Knopf K, Kloas W (2001): Induction of stress by the swimbladder nematode Anquillicola crassus In European eels, Anquilla anquilla, after repeat experimental infection. Parasitology 123: 179-184.

25.Lefebvre F, Crivelli AJ (2012): Salinity effects on anquillicolosis in Atlantic eels: a natural tool for disease control, The fallowing suplement accompanies the article. Marine Ecology Progress Series 471: 193-202.

26. Neto AF, Costa JL, Costa MJ, Domingos I (2010): Epidemiology and pathology of Anqullicoloides crassus in European eel Anquilla anquilla from the Tagus estuary (Portugal). Dis Aquat Organ 88: 225-233.

27. Neto AF, Passos D, Costa JL, et al. (2014): Infection of Anquilla anquilla by the parasite Anquillicoloides in Portuguese brackich water systems. Cah Biol Mar 55: 213-216.

28. Peters G, Hartmann F (1986): Anguillicola, a parasitic nematode of the swim bladder spreding among eel populations in Europe. Dis Aquat Organ 1: 229-230.

29. Garbacik-Wesołowska A, Szkudlarek A, Sobecka E (1994): Nematode Anguillicola crassus in eels from the Szczecin Lagoon and Lake Łętowskie. Bull Sea Fish Inst 2: 34-37.

30. Sures B, Streit B (2001): Eel parasite diversity and intermediate host abundance in the River Rhine, Germany. Parasitology 123: 185-191.

31.Knopf K, Lucius R (2008): Vaccination of eels (Anguilla japonica and Anguilla anguilla) against Anguillicola crassus with irradiated L3. Parasitology 135: 633-640.

32.Muńoz P, Peńalver J, Ruiz de Ybańez R, Garcia J (2015): Influence of adult Anguillicoloides crassus load in European eels swimbladder on macrophage response. Fish Shellfish Immunol 42: 221-224.

33.Knopf K (2006): The swimbladder nematode Anguillicola crassus in the European eel Anguilla Anguilla and the Japanes eel Anguilla japonica: differences in susceptibility and immunity between a recently colonized host and the original host. J Helminthol 80: 129-136.

34. Kirk RS (2003): The impact of Anguillicola crassus on European eels. Fish Manag Ecol 10: 385-394.

35. Yildiz HY (2006): Plasma lysozyme levels and secondary stress response in rainbow trout, Oncorhynchus mykiss (Walbaum) after exposure to Leteux-Meyer mixture. Turkey J Anim Sci 30: 265-269.

36. Roed KH, Fevolden SE, Fjalestad KT (2002): Disease resistance and immune characteristics in rainbow trout (Oncorhyn- chus mykiss) selected for lysozyme activity. Aquaculture 209: 91-101.

37. Roed KH, Larsen HJS, Linder RD, Refstie T (1993): Genetic variation in lysozyme activity in rainbow trout (Oncorhynchus mykiss). Aquaculture 109: 237-244.

38. Aleksander JB (1985): Non-immunoglobulin humoral defence mechanisms in fish. In: Fish Immunology. Academic Press, London; 133-140. 